\title{
John Donne : A Great Poet
}

Dr. Rajiv Kumar

Assistant Professor

Department of English

Kedar Sant Ramashraya Mahavidyalay, Sarairanjan,

Samastipur, Bihar, India

rkjha.jagran@gmail.com

\section{Abstract:}

John Donne is one of the greatest of English religious poets, and the poets of the 17th century on whom his influence was most deep and lasting than all religious poets. As Joan Bennett tells us this is so because his temperament was essentially religious. A man of religious temperament is constantly aware, constantly perceiving the underlying unity, the fundamental oneness of all phenomena, and the perception of such a relationship, such an inherent principle of unity, is revealed even by the imagery of the earliest poetry of Donne. No doubt Donne's religious poetry belongs to the later part of his career, to the period after his ordination, and the gloom, despair and frustration which resulted from the death of his wife, poverty, and illhealth. The earliest of his religious poems are the sonnet-sequence called La Corona 
and The Litanie; the best of his religious poetry is contained in the Holy Sonnets, the Divine Poems and The Three Hymns. The best of Donne's religious poetry was written only during the last phase of his career, but the nature of his imagery, even the early one, clearly indicated that his genius was religious and he was bound to take to religious poetry and to the pulpit.

Keywords: Metaphysical, devotional ,ordination, religious, divine.

Intoduction

Donne's poems made their mark early on and nothing to suggest that Donne was well known at all, much less as a poet, until he was in his middle years. Sir Geoffrey Keynes has pointed out that the ViceChancellor of the University of Cambridge appeared to know little of Donne when he admitted him (perforce) to a D.D. in 1615, and that Donne first made a name for himself when he published his Devotions and sermons in the $1620 \mathrm{~s} .{ }^{1}$ As far as we know, no one mentions or quotes in print a single poem of Donne's until 1598, when he was already twenty-six years old, and there is nothing after that until 1607 when he was thirty-five years old.

Donne's religious poetry until 1628, when Donne was fifty-six. Walton first named particular Divine Poems in his elegy for Donne in the 1633 edition. No writer quoted a Divine Poem, as far as we know, until 1635 when James Howell took up some ideas and phrases from 'Goodfriday, 1613. Riding Westward' in his Epistolae Ho-Elianae. Donne was unquestionably a very well-known Dean of St Paul's, and devout writer, of whom Huygens could justly report in 1630 that 'he is more famous than anyone'. Huygens tells us that it was this general esteem which at last led Donne's friends to distribute his poems in manuscript. But whatever Donne's fame in his later years, as poet or as preacher, such evidence as we have indicates that most of his poetry was 
not widely known before it was published in 1633. A very few pieces had a certain currency and fame in themselves but even some of the poems thus acknowledged were known because they had been published or set to music. The cult of Donne the master poet is no invention, but it is a phenomenon of the mid-seventeenth century when Donne was long dead. The first publication of Donne's collected poems in 1633, two years after his death, represented a considerable effort of garnering and assembly on the part of the unknown editor, whose printer offered them to the world with a flourish as writings of secure indeed unparalleled reputation: 'the best judgments...take it for granted' that Donne's poems are 'the best in this kind, that ever this kingdom hath yet seene'. Both the number and the quality of the tributes to Donne assembled in the volume indicate that the publication was no ordinary event; though rather few of his elegists actually mention his poetry, let alone praise particular poems, and only one of them presents him as something other than a great divine who expressed his piety in verse. Further editions of the poems quickly followed as publishers sought to meet a persisting demand. There were three editions within eight years of Donne's death, a further three editions in the following fifteen years, then a fifteen-year gap before the edition of 1669; and it was fifty years before another edition appeared, in 1719 , the last true edition of the poems for nearly a century and a half. By the mid-1630s poets were familiarly drawing on the Songs and Sonnets, and quotations from them or adaptations of them continued in a flood through the middle of the century; in fact people went on quoting Donne or referring to his lines down to the end of the century. Carew's elegy in the 1633 edition specifically celebrated Donne's poetic achievement, hailing Donne above all as a great poet who had decisively influenced English poetry. 
But although the Divine Poems are not the record of discoveries, but struggles to appropriate a truth which has been revealed, that truth does ri "defeat all Poetry", but gives us a poetry whose intensity is a moral intension. Some religious poetry, Herbert's perhaps, can be regarded as a species love-poetry; but Donne's is not of that kind. The image of Christ as Lo appears in only two of his poems both written soon after the death of wife. The image which dominates his divine poetry is the image of Chris Savior, the victor over sin and death. The strength with which his imagination presents this figure is the measure of his need, and that need is the subject. the finest of his religious poems. Donne's learning was enormous; and yet his sermons probably owe more to his knowledge of men than to his knowledge of books. e penitent is too apt to shrink into the recluse. Donne never yielded to this temptation. He himself thus rebukes the mistaken extravagance of penitence: "When men have lived long from God, they never think they come near enough to Him, except they go beyond Him."2

In Donne' s poetry, there is always an intellectual analysis of emotion. Every lyric arises out of some emotional situation, and the emotion concerned is analysed threadbare. Like a clever lawyer Donne gives arguments after arguments in support of his point of view. Thus in Valediction: Forbidding Mourning he proves that true lovers need not mourn at the time of parting; in the Canonisation he establishes that lovers are saints of love:, and in the Blossome he argues against the Petrarchan love tradition. This imparts to his poetry a hard intellectual tone, but it also results in that, "unification of sensibility", for which TS. Eliot praised the Metaphysical poetry so highly.

John Donne is the most remarkable of English poets. In a strict sense, he was a true Elizabethan who, however, led a most daring revolt against the conventional 
romanticism of Elizabethan love poetry. The Elizabethans were dominated both by spenser and petrach the Italian poet. Pastoral poetry, allegories, and conventional love-poetry were the order of the day. Donne was a sworn enemy of convention and monotonous form. Especially, he despised the harmonious cadences and highly regular of his contemporaries. He violated the conventional rhythms and traditional poetic expressions. He proclaimed his revolt with a resounding trumped sound. "I sing not siren-like to tempt; for I am harsh'. He broke fresh ground both in subject matter and style.

Donne has been classified both by Dryden and Samuel Jonson as a "metaphysical poet". This title has been conferred on him because of "his sudden flight from the material to the spiritual sphere" and also because of him obscurity which is occasionally baffling. His work abounds in wit and conceits are the very soul and stuff of a poet because his style is overwhelmed with obscure philosophical allusions and subtle and abstract references to science and religion. He set a fashion for metaphysical conceits and influenced a number of contemporary poets like Crashw and Cowley.

\section{Conclusion}

Donne's treatment of love is entirely unconventional. He does not fall in line with the ways and modes of feeling and expression found in the Elizabethan love poetry. Most of the Elizabethan poets followed the fashion set by Petrarch, an Italian sonneteer, in his treatment of love. According to the fashion the lover was always subject, humble, and over-respectful. Obedience to his mistress's wishes was his chief virtue. He sighed, wept, yearned, pined, and laguishead for her. The beloved's 
coldness and indifference did not damp his enthusiasm. In fact, petrarch, had been widily imitated, Besides, the Elizabethan poets were fond of making plentiful references to Greek gods and goddesses like Cupid and Venus in their love poetry.

Donne rebels against these stale and hackneyed conventions of love poetry. $\mathrm{He}$ rejects the lofty cult of the woman. She is no deity or goddess to be worshipped. He ridicules and laughs at her. This attitude is best revealed in the Song: "Go And catch a falling star', where he says that nowhere lives a woman true and fair, and that even the truest woman is false to several men. This poem is a brilliant pieces of mockery. Even in his defeat Donne rises superior to the woman. Her faithlessness to him only makes her look stupid and cheap. In Twicknam Garden also, he refers to woman As the perverse sex, and says that it is wrong to judge a woman's thoughts by her tears. In fact, his attitude in this poem is a mixture of scorn foe the fair sex and praise for the particular woman.

Donne and his followers made an excessive use of conceits. While in Shakespeare or Sydney a conceit is an ornament or an occasional grace, in Donne it is everywhere. It is his very genius, and fashions his feeling and thought. Donne's conceits are more intellectual than those of Shakespeare or Sydney. It is chiefly on account of the excessive use of intellectual and far-feched conceits that Donne is Known as a metaphysical poet. He employs acholastic, superstitious, skeptical, theological, and mathematical conceuts.

Being more often intellectual than emotional, these conceits make Donne's poetry difficult. We find it hard to get the meaning of most of his conceits without guidance of notes. They puzzle and perplex us. At the same time when we succeed in understanding them, we feel a certain pleasure as we feel after having solved a 
difficult mathematical problem. They make Donne's poetry obscure and novelty to his poetry.

A distinguishing quality of Donne's poetry is what may be called dissonance. Just as in music, a dissonant chord is sometime struck to produce a certain artistic effect, similarly Donne employed dissonances in his poetry. "the spider love", in Twicknow Garden is an example of this. Usually a poet is expected to use decorative and attractive pictures when talking of love. But Donne mentions the spider, thus striking a note highly dissonant with the reader's expectation. Sometimes, dissonance is produced by diction which offers contrast in dignity or general associations.

Except for the new religious motives behind the stress on Donne's "conversion," the Victorians gave the same preponderance as their predecessors to such qualities in the metamorphosed Donne as his benevolence, charity, and friendship. 


\section{Works Cited}

Introductory note to the catalogue of 'An Exhibition to Celebrate the Work and Reputation of John Donne 1572-1631', 1972, p. 2. The exhibition was presented in the Cambridge University Library from 23 October to 23 December 1972.

Works, vol. ii. p. 31 . 